\title{
Metrics CAPTURING THE DEGREE TO WHICH INDIVIDUAL ECONOMIES ARE GLOBALIZED
}

\author{
RAYMOND RIEZMAN \\ JOHN WHALLEY \\ SHUNMING ZHANG
}

\author{
CESIFO WORKING PAPER NO. 1450 \\ CATEGORY 7: TRADE POLICY \\ APRIL 2005 \\ PRESENTED AT VeNiCE SUMMER INSTITUTE, WORKSHOP ON \\ “Dissecting GlobalizATION", July 2004
}
An electronic version of the paper may be downloaded
- from the SSRN website: Www.SSRN.com
- from the CESifo website: www.CESifo.de




\title{
METRICS CAPTURING THE DEGREE TO WHICH INDIVIDUAL ECONOMIES ARE GLOBALIZED
}

\begin{abstract}
We discuss metrics of globalization for individual economies as distance measures between fully integrated and trade restricted equilibria in economies initially operating under less than full integration with the global economy. Such metrics can be used to construct country globalization metrics reflecting the distance of economies from full global integration due to trade barriers, barriers to factor flows, barriers to international financial intermediation, solved technological diffusion and other economy specific features yielding less than full integration into the global economy. Many distance metrics present themselves and none are wholly satisfactory since they each behave differently across various displacements from integration. Distance measures can, for instance, be small in goods space but large in price space. We present alternative measures constructed for eight OECD economies and comment in a concluding section on other measures used elsewhere in the literature such as trade / GDP ratios.
\end{abstract}

JEL Code: F00, F11, F15.

Raymond Riezman

University of Iowa

Department of Economics

W360 PBB

Iowa City, IA 52242

USA

\author{
John Whalley \\ Department of Economics \\ University of Western Ontario \\ London, Ontario, N6A 5C2 \\ Canada \\ jwhalley@uwo.ca
}

raymond.riezman@uiowa.edu

\author{
Shunming Zhang \\ Department of Economics \\ University of Western Ontario \\ London, Ontario, N6A 5C2 \\ Canada \\ szhang4@uwo.ca
}




\section{Introduction}

Globalization is simultaneously one of the most overused and ill defined terms in contemporary policy discussion, and conveys different things to different disciplinary researchers. Some of these meanings are discussed in Whalley (2004). Our point of departure relative to the current literature is to focus on the measurement of globalization, asking how globalized are particular economies, and how rapidly (or slowly) is globalization occurring?

Various indices of the extent of globalization appear in popular discussion. The Economist, for instance, publishes an annual index of globalization ${ }^{1}$ in which Singapore typically appears as the most globalized of all national economies. ${ }^{2}$ It is also commonly argued that the world economy today is as integrated as it was in 1913 (see Cable (1995) and Irwin (2001)). Are these positions able to be substantiated through constructed measures of globalization? Typically, such indices rely on trade/GDP ratios and other variables which are larger for small entrepot economies.

Our approach here is to stay within the globalization discussion emphasized in the analytically based economics literature which takes globalization to be ever deeper market based economic integration. The emphasis is on more trade and investment flows, increased international labour mobility, more rapid execution of cross border transactions rather than the governance and identity issues stressed by political scientists and sociologists. We ask how metrics of the degree to which individual economies are globalized may be developed and calculated.

Following the classical general equilibrium trade literature, we discuss how close particular economies are to an equilibrium that would characterize full integration into the global economy (such as free trade in goods, full factor mobility, or both) assuming such equilibria are unique. There is little or no literature we are aware of which explicitly compares equilibria using distance metrics ${ }^{3}$; the main focus of prior general equilibrium literature being on com-

\footnotetext{
${ }^{1}$ Another such index is published annually in Foreign Policy, see the March - April 2004 issue.

${ }^{2} \mathrm{But}$ on the basis of commodity price comparisons to neighbouring economies (particularly Malaysia) Singapore would appear as substantially less fully integrated into the global economy than many other economies.

${ }^{3}$ Measures of distance between equilibria are also critical in a number of other curremt subareas of economics. In the calibration area, for instance, inexact calibration (see Dawkins, Srinivasan, and Whalley (2001)) involves choosing parameter values for equilibrium structures so as to produce model generated equilibria as close as possible to observed data (pre-adjusted for compatibility with model equilibrium conditions), and closely related metrics of distance between equilibria are also needed here.
} 
parative statics and issues of existence, uniqueness, and stability (see Arrow and Hahn (1971), and Mas-Colell (1985)). Our analysis, therefore, forms part of a wider discussion of how far equilibrium observations for economies are from other hypothetical equilibria; in this case those that would be generated under complete openness (free trade and free factor flows).

In what follows, we first formalize alternative metrics of globalization as distance measures between equilibria, and then explore the behavior of these metrics using data on simple forms of restricted equilibria for some sample economies. We use data for eight OECD countries (Australia, Germany, Italy, Japan, Korea, Mexico, UK, US) to make calculations of metrics of globalization using these measures. These are chosen as a sample of countries varying by size, level of income per capita, trade pattern, and size of trade barriers.

We calibrate a simple general equilibrium model to observed data reflecting less than full integration in the presence of existing trade barriers, and then use the model parametrizations generated in this way to compute counterfactual free trade equilibria. The next step is construct various globalization distance metrics between observed and counterfactual equilibria for each country. We first consider direct price and quantity measures of distance, calculating the sum of squares of differences in either prices or quantities (or both) between equilibria. The second measure looks at the absolute value of excess demands. Equilibrium prices of one equilibrium are introduced into the model generating the other equilibrium to generate the excess demands. Measures are constructed for both goods or factors excess demands. We finally construct endowment change metrics of distance following Debreu (1951), which also require explicit model structures and parameters for their implementation.

Our conclusion from the calculations we report on is that these globalization distance metrics can behave in different ways and numerical measures of the degree of globalization can therefore be hard to interpret. No unambiguously preferred metric seems to offer itself, despite the growing importance attached to distance metrics in globalization debate. We then pursue a more limited objective, namely to construct relative globalization measures. That is, can the data tells us which countries are more globalized than others? Here we are more successful. The data provide some guidance as to which countries are relatively more globalized. Parallels to the literature on inequality measures are also drawn. 


\section{The Analytics of Globalization Distance Measures}

In this section we develop some analytics for distances measure which can be used to assess how close to or far away the equilibrium for a particular economy is from that which would characterize full integration into the global economy. We assume that we are to compare a trade (or factor flow) restricted equilibrium to a full integration equilibrium and only one of these equilibria will be observed (typically an equilibrium in the presence of trade and factor flow restrictions). We thus first calibrate models to data on actual economies in the presence of such restrictions, and then use the parametrizations generated for these models to compute unobservable free trade equilibrium. We make the strong assumption in what follows that both free trade and restricted equilibria are unique ${ }^{4}$.

We begin with some simple measures of distance between two equilibria, calculated by summing the squares of differences across equilibria in endogenous variables (prices, quantities), noting that these are several issues which arise with such measures. One is that if price variables are involved they are not invariant to alternative price normalizations. Another is that the rationale for including all variables in such measures (such as both prices and quantities) is not clear, while neither is it clear that some variables should be excluded. If only a subset of variables are included in such distance measures one has to rationalize which they are and why they should be used. Hence, we choose to calculate distance measures for price and quantity for both goods and factors of production.

The second type of distance measure we develop involves computing excess demands at nonequilibrium prices. For these measures we take the prices from one equilibrium and use them in the model of the economy generating the other equilibrium and calculate the size of the implied excess demands. In the small open economy case, domestic prices are given by world prices gross of tariffs. If we calibrate a model using gross of tariff prices, we can then introduce net of tariff prices and recompute the excess demands (i.e. trade in the form of imports and exports). We take the absolute value of the change in excess demands relative to total demands as the distance measure between the two equilibria. These are model dependent measures in that the numerical value of the distance measure will vary as the underlying model parametrization used to calibrate to the equilibrium data changes (say, as elasticities of substitution and share parameters in CES functions change).

\footnotetext{
${ }^{4}$ But see the discussion of the likelihood of multiplicity of equilibria in models similar to those we use in Kehoe (1991) and Whalley and Zhang (2004)
} 
These are also issues with these types of measures. One is that they are only operational in the sense of producing a single valued measure where there are point-to-point mappings (a pure exchange economy), not correspondences (economies with production). Another is that one can have pairs of equilibria under this class of measures which yield sharp differences in distance measures (close, far) in prices and quantities as indicated above.

Finally, we use a third class of distance measures in parameter space. These are measures in the spirit of the Debreu (1951) coefficient of resource utilization which yield the maximum proportional uniform shrinkage in the endowments of an economy that is possible subject to the constraint that the utility of a representative consumer is preserved as distortions are removed, a measure of the degree of inefficiency of an economy. Using this type of globalization metric implies that, in a two consumer, two good, two factor model of an economy, one computes the maximal proportional shrinkage for each of the two factor endowments which preserves utility for a simple representative consumer as trade barriers are removed.

That there is seemingly no satisfactory way of choosing between these alternative measures since there is no single measure which dominates all other measures. Each will yield a numerical measure of distance, and these metrics will behave differently across alternative pairwise equilibrium comparisons. One measure may indicate a large distance between equilibria and another small. The interpretation of such measures thus becomes an issue. What can one conclude, for instance, if endowments change by, say, $10 \%$ in a Debreu type measure in comparisons across equilibria while an excess demand calculation implies say a $50 \%$ measure for the same tariff barrier. Our propose is thus to raise the issue of which distance measures to use in the globalization debate and whether different measures are appropriate for different circumstances.

To show more concretely how measures of distance can be constructed between globalized and non-globalized equilibria, we take the simple case of a small open price taking economy with 2 produced goods and 2 factors of production. For this economy, there will be various features which limit integration into the global economy, such as tariffs, domestic taxes, quotas and other policy interventions. We assume these are present in the observed restricted equilibrium, but absent in the hypothetical globally integrated equilibrium.

For this economy, we assume two input CES production functions for the two goods which 
are given by

$$
Q_{j}=\phi_{j}\left\{\sum_{f} \delta_{j f} T_{j f}^{\frac{\sigma_{j}-1}{\sigma_{j}}}\right\}^{\frac{\sigma_{j}}{\sigma_{j}-1}}, \quad j=1,2
$$

where $Q_{j}$ denotes output of the $j$-th industry, $\phi_{j}$ is the scale or units parameter, $\delta_{j f}$ is the distribution parameter $\left(\sum_{f} \delta_{j f}=1\right), T_{j f}$ is the labor and capital factor input $(f=L, K)$, and $\sigma_{j}$ is the elasticity of factor substitution.

The factor demand functions derived from cost minimization for these production functions (1) are:

$$
T_{j f}=\frac{Q_{j}}{\phi_{j}}\left[\frac{B_{f}}{\delta_{j f}}\right]^{-\sigma_{j}}\left\{\sum_{f^{\prime}} \delta_{j f^{\prime}}\left[\frac{B_{f^{\prime}}}{\delta_{j f^{\prime}}}\right]^{1-\sigma_{j}}\right\}^{\frac{\sigma_{j}}{1-\sigma_{j}}}, \quad j=1,2 \quad f=L, K
$$

where $B_{f}$ is the price of factor $f$ (per-unit factor costs for the industry).

On the demand side of the economy we consider a representative consumer with a CES utility function given by

$$
U=\left\{\sum_{j} \alpha_{j}^{\frac{1}{\sigma}} X_{j}^{\frac{\sigma-1}{\sigma}}\right\}^{\frac{\sigma}{\sigma-1}}
$$

where $X_{j}$ is the quantity of good $j$ demanded by the consumer, $\alpha_{j}$ is the share parameter $\left(\sum_{j} \alpha_{j}=1\right)$, and $\sigma$ is the substitution elasticity in the consumer's CES utility function.

Consumer income has three parts, endowment income $\sum_{f} B_{f} W_{f}$, tariff revenue $\sum_{j} r_{j}^{F} P_{j}^{0} Z_{j}$ and a foreign resource transfer $R$ reflecting the financing of any trade imbalance ${ }^{5}$. We assume $R$ to be exogenous and fixed in real terms (i.e. indexed to a measure of the price level).

$$
I=\sum_{f} B_{f} W_{f}+\sum_{j} r_{j} P_{j}^{0} Z_{j}+R
$$

where $W_{f}(f=L, K)$ is the consumer's endowment of labor and capital, $Z_{j}=X_{j}-Q_{j}$ is the import and export of good $j$ (excess demands for goods).

World prices for goods are $P_{j}^{0}$ and are taken as given exogenously, and the tariff rate on imports of goods $j$ is $r_{j} . r_{j}>0$ if good $j$ is imported $\left(X_{j}>Q_{j}\right)$, and $r_{j}=0$ if $\operatorname{good} j$ is exported $\left(X_{j} \leq Q_{j}\right)$. The domestic price of good $j$ is $P_{j}=\left(1+r_{j}\right) P_{j}^{0}$.

The consumer's budget constraint is

$$
\sum_{j} P_{j} X_{j}=I
$$

${ }^{5}$ We incorporate the trade imbalance in this way since typically for actual economy data to be used in model calibrateion will not bo consistent with zero trade balance 
where $P_{j}$ is the consumer price for good $j$.

Demand functions from utility maximizing behavior are

$$
X_{j}=\frac{\alpha_{j} I}{P_{j}^{\sigma} \sum_{j^{\prime}} \alpha_{j^{\prime}} P_{j^{\prime}}^{1-\sigma}}, \quad j=1,2
$$

The equilibrium conditions in this model are that market demand equals market supply for all factors, and that profits are zero in each industry. Goods markets will be characterized by domestic excess demands that meet the trade imbalance constraint. These equilibrium conditions are that

[1] Demands equal supply for factors

$$
\sum_{j} T_{j f}=W_{f}, \quad f=L, K
$$

[2] Zero profit conditions hold in both industries

$$
\sum_{f} B_{f} T_{j f}=P_{j} Q_{j}, \quad j=1,2
$$

For this economy, an equilibrium is characterized by factor prices $B_{L}$ and $B_{K}$, and domestic prices $P_{1}$ and $P_{2}$ (given world prices $P_{1}^{0}$ and $P_{2}^{0}$ ), such that equations (7) and (8) hold.

From equations (2) and (8) we have

$$
\sum_{f} \delta_{j f}\left[\frac{B_{f}}{\delta_{j f}}\right]^{1-\sigma_{j}}=\left[\phi_{j} P_{j}\right]^{1-\sigma_{j}}, \quad j=1,2
$$

Defining excess demands for factors as

$$
Y_{f}=\sum_{j} T_{j f}-W_{f}, \quad f=L, K
$$

and excess demand of goods

$$
Z_{j}=X_{j}-Q_{j}, \quad j=1,2
$$

the equilibrium conditions can be rewritten as [1] excess demands for factors are zero, i.e. $Y_{f}=0, f=L, K$; and [2] zero profit conditions hold in both industries (i.e. Equation (8)).

At such an equilibrium we can also show that the trade imbalance constraint is satisfied. Using full employment condition (7) and zero profit conditions (8), we have

$$
I=\sum_{j} P_{j} Q_{j}+\sum_{j} r_{j} P_{j}^{0} Z_{j}+R
$$


from equation (4). Rewriting the budget constraint (5) as

$$
\sum_{j} P_{j} X_{j}=\sum_{j} P_{j} Q_{j}+\sum_{j} r_{j} P_{j}^{0} Z_{j}+R
$$

that is,

$$
\sum_{j}\left(1+r_{j}\right) P_{j}^{0} Z_{j}=\sum_{j} P_{j} Z_{j}=\sum_{j} r_{j} P_{j}^{0} Z_{j}+R
$$

from the excess demand of goods equation (11), and

$$
\sum_{j} P_{j}^{0} Z_{j}=R
$$

which is trade balance.

Into this economy, we can introduce a wide range of trade distorting instruments beyond tariffs, such as domestic taxes and quotas. All of these policy interventions will limit the degree of integration of the economy into the wider global economy. Assuming for now that equilibria in this economy are unique, this economy has two equilibria for case with and without policy interventions. We label these restricted and unrestricted economies as $E^{(1)}$ and $E^{(2)}$. Typically we will use an observed equilibrium $E^{(1)}$ and a model parametrization will be calibrated from the equilibrium data consistent with it. The other equilibrium $E^{(2)}$ will be computed as a counterfactual equilibrium. We can also construct various distance measures between equilibria for different barriers applying to the imported good. These equilibria we also characterize by the variables $\left(B_{f}^{(1)}, P_{j}^{(1)}, Q_{j}^{(1)}, X_{j}^{(1)}, T_{j f}^{(1)}\right)$ and $\left(B_{f}^{(2)}, P_{j}^{(2)}, Q_{j}^{(2)}, X_{j}^{(2)}, T_{j f}^{(2)}\right)$.

We first consider simple normalized Euclidean distance measures between restricted and unrestricted equilibria in prices and quantities as

$$
\begin{gathered}
M_{B}=\frac{\sqrt{\sum_{f=L, K}\left[B_{f}^{(1)}-B_{f}^{(2)}\right]^{2}}}{\frac{1}{4} \sum_{m=1}^{2} \sum_{f=L, K} B_{f}^{(m)}} \\
M_{P}=\frac{\sqrt{\sum_{j=1,2}\left[P_{j}^{(1)}-P_{j}^{(2)}\right]^{2}}}{\frac{1}{4} \sum_{m=1}^{2} \sum_{j=1}^{2} P_{j}^{(m)}} \\
M_{Q}=\frac{\sqrt{\sum_{j=1,2}\left[Q_{j}^{(1)}-Q_{j}^{(2)}\right]^{2}}}{\frac{1}{4} \sum_{m=1}^{2} \sum_{j=1}^{2} Q_{j}^{(m)}} \\
M_{T}=\frac{\sqrt{\sum_{j=1,2} \sum_{f=L, K}\left[T_{j f}^{(1)}-T_{j f}^{(2)}\right]^{2}}}{\frac{1}{8} \sum_{m=1}^{2} \sum_{j=1}^{2} \sum_{f=L, K} T_{j f}^{(m)}}
\end{gathered}
$$




$$
M_{X}=\frac{\sqrt{\sum_{j=1,2}\left[X_{j}^{(1)}-X_{j}^{(2)}\right]^{2}}}{\frac{1}{4} \sum_{m=1}^{2} \sum_{j=1}^{2} X_{j}^{(m)}}
$$

Constructing these measures requires data on the two equilibrium outcomes. The measures $M_{B}$ and $M_{P}$ are dependent on the choice of price normalization.

We can also construct excess demand measures between the two economies: $E^{(1)}$ and $E^{(2)}$ and their equilibria: $\left(B_{f}^{(1)}, P_{j}^{(1)}, Q_{j}^{(1)}, X_{j}^{(1)}, T_{j f}^{(1)}\right)$ and $\left(B_{f}^{(2)}, P_{j}^{(2)}, Q_{j}^{(2)}, X_{j}^{(2)}, T_{j f}^{(2)}\right)$ are the associated variable values. We assume $E^{(1)}$ in the presence of barriers is observed, and we then eliminate the tariff in the case where this is the trade barrier and introduce the net of tariff prices into the model parametrization supporting $E^{(2)}$ and compute excess demands. This procedure does not yield an equilibrium solution to the model, but does suggest locally how large the change in excess demands for goods (factors) would be if trade barriers were eliminated.

We construct excess demand measures in factor space by introducing the production values $Q_{j}^{(2)}$ into the model supporting Economy $E^{(1)}$, and evaluating excess demand functions for factors $Y_{f}^{\left(1^{\prime}\right)}$ given by equation (10). Given $Q_{j}^{(2)}$, we solve for $T_{j f}^{\left(1^{\prime}\right)}$ from Equation (2), for $j=1,2$ and $f=L, K$,

$$
T_{j f}^{\left(1^{\prime}\right)}=\frac{Q_{j}^{(2)}}{\phi_{j}}\left[\frac{B_{f}^{(1)}}{\delta_{j f}}\right]^{-\sigma_{j}}\left\{\sum_{f^{\prime}} \delta_{j f^{\prime}}\left[\frac{B_{f^{\prime}}^{(1)}}{\delta_{j f^{\prime}}}\right]^{1-\sigma_{j}}\right\}^{\frac{\sigma_{j}}{1-\sigma_{j}}}=\frac{Q_{j}^{(2)}}{Q_{j}^{(1)}} T_{j f}^{(1)}
$$

and generate the excess demands for factors $Y_{f}^{\left(1^{\prime}\right)}=\sum_{j} T_{j f}^{\left(1^{\prime}\right)}-W_{f}(f=L, K)$ as in equation (10). This yields a factor excess demand measure between $E^{(1)}$ and $E^{(2)}$ as

$$
M F_{1}=\frac{\sum_{f} B_{f}^{(1)}\left|Y_{f}^{\left(1^{\prime}\right)}\right|}{\sum_{j} \sum_{f} B_{f}^{(1)} T_{j f}^{\left(1^{\prime}\right)}}
$$

In this evaluation of factor excess demands full employment conditions do not hold, and so consumer' income is given

$$
I^{\left(1^{\prime}\right)}=\sum_{f} B_{f}^{(1)} W_{f}+\sum_{j} r_{j}^{(1)} P_{j}^{0} Z_{j}^{\left(1^{\prime}\right)}+R
$$

where $Z_{j}^{\left(1^{\prime}\right)}=X_{j}^{\left(1^{\prime}\right)}-Q_{j}^{(2)}$. Solving for consumption $X_{j}^{\left(1^{\prime}\right)}$ from Equation (6), for $j=1,2$,

$$
X_{j}^{\left(1^{\prime}\right)}=\frac{\alpha_{j}\left\{\sum_{f} B_{f}^{(1)} W_{f}+\sum_{j} r_{j}^{(1)} P_{j}^{0}\left[X_{j}^{\left(1^{\prime}\right)}-Q_{j}^{(2)}\right]+R\right\}}{\left[P_{j}^{(1)}\right]^{\sigma} \sum_{j^{\prime}} \alpha_{j^{\prime}}\left[P_{j^{\prime}}^{(1)}\right]^{1-\sigma}}
$$


we can also generate an excess demand distance measure between $E^{(1)}$ and $E^{(2)}$ in terms of goods excess demands $Z_{j}^{\left(1^{\prime}\right)}$ using Equation (11). This yields a goods excess demand measure of distance between $E^{(1)}$ and $E^{(2)}$ as

$$
M G_{1}=\frac{\sum_{j} P_{j}^{(1)}\left|Z_{j}^{\left(1^{\prime}\right)}\right|}{\sum_{j} P_{j}^{(1)} X_{j}^{\left(1^{\prime}\right)}}
$$

We can finally construct Debreu type shrinkage measures of distance between the two Economies: $E^{(1)}$ and $E^{(2)}$ and their equilibria: $\left(B_{f}^{(1)}, P_{j}^{(1)}, Q_{j}^{(1)}, X_{j}^{(1)}, T_{j f}^{(1)}\right)$ and $\left(B_{f}^{(2)}, P_{j}^{(2)}, Q_{j}^{(2)}\right.$, $\left.X_{j}^{(2)}, T_{j f}^{(2)}\right)$ are the associated variable values. To do this we use $P_{j}^{(2)}$ in the model specification supporting Economy $E^{(1)}$, and compute an equilibrium for the case here tariffs are eliminated and there is a supporting endowment of factors $W_{f}^{\left(1^{\prime}\right)}=\left[1+M D_{1}\right] W_{f}^{(1)}$ which yields unchanged utility for the representative consumer. $M D_{1}$ yields the Debreu type shrinkage measure of distance between the two equilibria $E^{(1)}$ and $E^{(2)}$. 


\section{Applying Globalization Distance Metrics to Actual Economies}

To investigate how the distance measures set out above behave in practice, and what numerical measures of globalization distance are implied for particular economies, we have used the simple 2 good, 2 factor trade model set out above to construct globalization distance measures for a sample of OECD economies. We use the OECD STAN database for 2000 which provides consistent data on consumption, production, and trade for all OECD economics. Into this we also introduce measures of average tariff rates on imports taken from OECD sources. We find this OECD data simpler to use and in some ways more applicable to our needs than the GTAP data base.

The procedures set out in Section 2 are relatively simple to implement, but there are a number of issues of detail that arise. One is that in a model in which factors are fully mobile the production frontier will be close to linear for conventional functional forms such as Cobb Douglas and CES unless share and substitution parameters differ sharply across sectors. This means that for a small tariff change the model will be driven to specialization and as a result will be difficult to fit to the data. In order to get around this problem, we restrict ourselves to compute globalization distance measures for sufficiently small tariff reductions that specialization does not occur in the model.

Also, calculating globalization distance measure in practice requires a number of prior judgment calls in the use and interpretation of data, as is typical in most subjective numerical modelling in economics. In our empirical implementation of distance metrics, we first need to select our sample of countries. We have chosen Australia, Germany, Italy, Japan, Korea, Mexico, UK, US as our sample of OECD economies since these differ in size, their trade patterns, their levels of development, and their degree of openness. We take data for the year 2000 for each of these economies and consider each of them in isolation from each other, modelling each country as a small open price taking economy (clearly a strong assumption in the US case).

We construct an initial base case data set reflecting an equilibrium for each of these economies in the presence of domestic trade restrictions, which for simplicity we limit to tariffs. The equilibrium data are set out in Table 1. To generate this data set we take information from the STAN database in value terms in domestic currency from which we assemble consumption, production, factor by sector, and net trade for each country for the year 2000 . 
Table 1 Value Data Reflecting Assumed 2000 Benchmark Equilibria for a Sample of OECD Economies ${ }^{1}$

\section{(Country Data in Domestic Currency ${ }^{2}$ )}

\begin{tabular}{|c|c|c|c|c|c|c|c|c|}
\hline & Australia & Germany & Italy & Japan & Korea & Mexico & UK & US \\
\hline \multicolumn{9}{|c|}{ Value of Output } \\
\hline $\mathrm{NM}^{3}$ & 55,593 & 27,750 & 35,534 & 7,772 & 26,320 & 272,188 & 34,109 & 267,362 \\
\hline$M^{3}$ & 73,354 & 423,220 & 220,604 & 112,114 & 163,283 & $1,013,597$ & 153,671 & $1,520,263$ \\
\hline \multicolumn{9}{|c|}{ Value of Factor Use } \\
\hline$L^{3}-N M$ & 10,505 & 15,870 & 8,314 & 2,382 & 3,115 & 51,105 & 6,163 & 89,190 \\
\hline $\mathrm{L}^{3}-\mathrm{M}$ & 40,296 & 310,640 & 122,207 & 59,506 & 59,670 & 311,239 & 110,483 & 981,781 \\
\hline $\mathrm{K}-\mathrm{NM}$ & 45,088 & 11,880 & 27,220 & 5,390 & 23,205 & 221,083 & 27,946 & 178,172 \\
\hline $\mathrm{K}-\mathrm{M}$ & 33,058 & 112,580 & 98,397 & 52,608 & 103,613 & 702,358 & 43,188 & 538,482 \\
\hline \multicolumn{9}{|c|}{ Value of Net Trade (Imports - Exports) } \\
\hline $\mathrm{NM}$ & $-23,421$ & 48,333 & 26,554 & 9,604 & 42,072 & $-131,025$ & $-0,325$ & 89,103 \\
\hline M & 49,096 & $-120,091$ & $-37,996$ & $-19,178$ & $-57,401$ & 145,532 & 36,799 & 321,348 \\
\hline \multicolumn{9}{|c|}{ Value of Consumption } \\
\hline NM & 32,172 & 76,083 & 62,088 & 17,376 & 68,392 & 141,163 & 33,784 & 356,465 \\
\hline M & 122,450 & 303,129 & 182,608 & 92,936 & 105,882 & $1,159,129$ & 190,470 & $1,841,611$ \\
\hline \multicolumn{9}{|c|}{ Initial Tariff Rate on Imports ${ }^{4}$} \\
\hline $\mathrm{NM}$ & 0.000000 & 0.208675 & 0.208675 & 0.158008 & 0.368725 & 0.000000 & 0.000000 & 0.109535 \\
\hline M & 0.105931 & 0.000000 & 0.000000 & 0.000000 & 0.000000 & 0.348223 & 0.041334 & 0.033641 \\
\hline
\end{tabular}

1 Sources: OECD STAN database plus Table 2

2 These value units in domestic currency are AUD $10^{6}$, EUR $10^{6}$, EUR $10^{6}$, JPY $10^{9}$, KRW $10^{9}, \operatorname{MXP} 10^{6}, \operatorname{GBP} 10^{6}$, and USD $10^{6}$.

3 In this table, M and NM denote Total Manufacturing and Non Manufacturing (Agriculture, Hunting, Forestry and Fishing; Mining and Quarrying); L and K denote Labour and Capital. 4 See Table 2 for the underlying data used to generate tariff averages reputed here. 
We use a two sector classification for each economy in which we first ignore all service related and non-tradable transactions such as utilities, government activity, retailing, wholesaling, distribution, banking, and financial services. We only consider two aggregate traded goods sectors which we take to reflect manufacturing and non-manufacturing activity. From the STANs data, "total manufacturing" is taken as manufacturing and "agriculture, fishing, forestry, and mining /quarrying" are taken as non-manufacturing. Since the $2 \times 2$ case requires as many factors as goods in the model, this is a relatively easy case to implement. Subsequent applications of this approach can easily (but more tediously) be applied to multisector, multifactor models and the change of the level of aggregation in data will clearly affect the numerical value of globalization measures generated.

STAN data give value added according to our sectorial classification, and also provide data on the compensation of employees. The return to capital is constructed by residual for each sector as the difference between the two. We make the strong assumption that the output of each sector is given only by the value added originating in the sector, and we ignore all intermediate transactions. This yields data on output and factor use by sector in value terms for each country for our benchmark year. This data is in value terms, and to produce equilibrium data on both prices and quantities we need to adopt a units convention for the measurement of both goods and factors. We follow the convention attributed to Harberger (1962) and discussed in Shoven and Whalley (1992) of assuming unitary prices for factors, and unitary world prices for goods in the trade distorted equilibrium. This yields domestic prices for imports as one plus the tariff rate.

We use the trade data in STANs on a net trade basis which nets out imports and exports (again in value terms) by good (for our 2 good classification) for each country. This yields consumption as production plus net trade. This substantially reduces trade volumes relative to published trade data. Most of the OECD economies we consider are net exporters of manufactured goods. Balanced trade does not hold for this net trade data by country since some countries have trade surpluses and others (notably the US) have trade deficits. One procedure to handle trade imbalances is to modify the data to force balanced trade; another is to use a model which incorporates a fixed trade imbalance (which is non-zero). We choose the latter procedure. For the US, this yields the feature that both goods are imported, and financed by foreign resource transfers supporting the observed trade imbalance.

We use tariff rate data from OECD sources as our trade barrier measure in the restricted 
equilibrium. This data is presented in Table 2 which reports the tariff data we have relied on for our barrier estimates. This data is from OECD Sources on bound tariff rates by Harmonized Nomenclature section headings, and this gives the fraction of line items in specified tariff lines falling in numerical ranges of tariff rates. We have aggregated this data using simple means for in sample ranges. We do not employ trade weighted average, nor use applied rather than bound tariff rates. There is a considerable literature on constructing tariff averages, which for simplicity we ignore. We use statutory rather than effective tariff rates. 
Table 2 OECD Data on Tariff Intervals by HS Section

(Post-Uruguay Round Bound Rates) by Country Used

to Calculate Country Tariff Rates in Table $1^{1}{ }^{2}$

(\% of Tariff Nomenclature Section Headings in Specified Rate Ranges by Country)

\begin{tabular}{|c|c|c|c|c|c|c|c|c|}
\hline $\begin{array}{c}\text { Tariff } \\
\text { Binding } \\
\text { Ranges }\end{array}$ & Australia & Germany & Italy & Japan & Korea & Mexico & UK & US \\
\hline \multicolumn{9}{|c|}{ Non Manufacturing } \\
\hline Duty Free & 32.6 & 26.5 & 26.5 & 31.0 & 2.2 & 0.1 & 26.5 & 27.9 \\
\hline $0-5 \%$ & 16.2 & 16.1 & 16.1 & 19.1 & 8.4 & 3.3 & 16.1 & 16.7 \\
\hline $5-10 \%$ & 1.6 & 9.3 & 9.3 & 6.7 & 16.6 & 3.0 & 9.3 & 2.0 \\
\hline $10-15 \%$ & 0.0 & 7.7 & 7.7 & 1.2 & 19.1 & 8.4 & 7.7 & 0.1 \\
\hline $15-20 \%$ & 44.0 & 12.2 & 12.2 & 22.0 & 7.2 & 0.0 & 12.2 & 48.1 \\
\hline $20-50 \%$ & 4.2 & 11.2 & 11.2 & 10.3 & 8.1 & 0.3 & 11.2 & 4.7 \\
\hline$>50 \%$ & 1.4 & 17.0 & 17.0 & 9.6 & 38.6 & 84.8 & 17.0 & 0.4 \\
\hline \multicolumn{9}{|c|}{ Manufacturing } \\
\hline Duty Free & 18.7 & 22.2 & 22.2 & 53.8 & 13.5 & 0.2 & 22.2 & 37.2 \\
\hline $0-5 \%$ & 19.6 & 43.0 & 43.0 & 28.4 & 7.1 & 0.0 & 43.0 & 39.6 \\
\hline $5-10 \%$ & 28.1 & 27.3 & 27.3 & 14.5 & 23.8 & 0.2 & 27.3 & 15.6 \\
\hline $10-15 \%$ & 17.7 & 7.0 & 7.0 & 2.7 & 36.8 & 0.0 & 7.0 & 5.6 \\
\hline $15-20 \%$ & 2.5 & 0.4 & 0.4 & 0.2 & 8.2 & 0.3 & 0.4 & 1.3 \\
\hline $20-50 \%$ & 11.6 & 0.2 & 0.2 & 0.4 & 10.5 & 99.2 & 0.2 & 0.8 \\
\hline$>50 \%$ & 1.7 & 0.0 & 0.0 & 0.0 & 0.2 & 0.0 & 0.0 & 0.0 \\
\hline \multicolumn{9}{|c|}{ Calculated Country Average Tariff Rates (Percentage) } \\
\hline $\mathrm{NM}$ & 10.7450 & 20.8675 & 20.8675 & 15.8008 & 36.8725 & 65.1276 & 20.8675 & 10.9535 \\
\hline M & 10.5931 & 4.1334 & 4.1334 & 2.3100 & 11.8107 & 34.8223 & 4.1334 & 3.3641 \\
\hline
\end{tabular}

1 Note: Calculations are report 6 - digit HS section headings.

2 Sources: Tariffs and Trade: OECD query and reporting system, OECD 2000. 
In the data in Table 1, the relative size of economies differs, as do trade patterns and factor use by sector, and initial tariff rates. This provides the benchmark equilibrium taken as observed for each of our sample OECD economies. We then calibrate each of our country models to this data which we assume for now to be generated in the presence of a tariff as the only trade barrier which creates distance from full integration. We then apply the procedures set out in the previous section to construct our globalization metrics.

In implementing these procedures, we have restricted ourselves to cases where the only barrier limiting full integration into the global economy is a tariff. In fact, there are many barriers which limit integration into the global economy including other trade measures (quotas, dumping and countervailing duties), national standards, differential regulation of financial institutions, transportation regulation, agricultural policies, and many others. Each of these would need an explicit model representation that sharply differs from a representation by an ad valorem equivalent tariff if they were to be sensibly incorporated into such analyses. Extensions of this approach can be used to analyze these barriers also; we have not done so since our purpose is to illustrate a general approach to constructing globalization metrics.

We calibrate the model set out in the previous section, for cases where the trade imbalance for each economy is non-zero. The calibration procedures we use are set out in Dawkins, Srinivasan and Whalley (2001). To implement calibration we rely on the literature to generate substitution elasticities by sector by country, and we use values roughly consistent with those reported in Piggott and Whalley (1985) and Hammermesh (1993) of 2.0 in non manufacturing and 0.5 in manufacturing.

Table 3 presents the calibrated model parameter values for the model we use for each country, along with model data on endowments and tariff rates. 
Table 3 Calibrated and Other Model Parameters by Country Reproducing the Equilibrium Data in Table 1

\begin{tabular}{|c|c|c|c|c|c|c|c|c|}
\hline & Australia & Germany & Italy & Japan & Korea & Mexico & UK & US \\
\hline \multicolumn{9}{|c|}{ Scale Parameters in Production } \\
\hline NM & 1.782958 & 1.646108 & 1.527880 & 1.659805 & 1.202613 & 1.781035 & 1.769515 & 1.751178 \\
\hline M & 1.790994 & 1.640678 & 1.976970 & 1.992457 & 1.864930 & 1.291180 & 1.611564 & 1.783280 \\
\hline \multicolumn{9}{|c|}{ Share Parameters in Production } \\
\hline $\mathrm{L}-\mathrm{NM}$ & 0.325550 & 0.536134 & 0.355946 & 0.399319 & 0.268142 & 0.324684 & 0.319547 & 0.414355 \\
\hline L - M & 0.597721 & 0.883905 & 0.606688 & 0.561295 & 0.249053 & 0.164137 & 0.867450 & 0.768743 \\
\hline $\mathrm{K}-\mathrm{NM}$ & 0.674450 & 0.463866 & 0.644054 & 0.600681 & 0.731858 & 0.675316 & 0.680453 & 0.585645 \\
\hline $\mathrm{K}-\mathrm{M}$ & 0.402279 & 0.116095 & 0.393312 & 0.438705 & 0.750947 & 0.835863 & 0.132550 & 0.231257 \\
\hline \multicolumn{9}{|c|}{ Share Parameters in Preferences } \\
\hline NM & 0.203951 & 0.208341 & 0.262811 & 0.162445 & 0.411299 & 0.101542 & 0.149360 & 0.164593 \\
\hline M & 0.796049 & 0.791659 & 0.737189 & 0.837555 & 0.588701 & 0.898458 & 0.850640 & 0.835407 \\
\hline \multicolumn{9}{|c|}{ Initial Endowment } \\
\hline $\mathrm{L}$ & 50,801 & 326,510 & 130,521 & 61,888 & 62,785 & 362,344 & 116,646 & 1070,971 \\
\hline $\mathrm{K}$ & 78,146 & 124,460 & 125,617 & 57,998 & 126,818 & 923,441 & 71,134 & 716,654 \\
\hline \multicolumn{9}{|c|}{ Substitution Elasticities in Production (All Countries) } \\
\hline NM & \multicolumn{8}{|c|}{2.0} \\
\hline M & \multicolumn{8}{|c|}{0.5} \\
\hline \multicolumn{9}{|c|}{ Substitution Elasticities in Consumption (All Countries) } \\
\hline \multicolumn{9}{|c|}{1.25} \\
\hline \multicolumn{9}{|c|}{ Initial Tariff Rate on Imports ${ }^{1}$ (Percentage) } \\
\hline NM & 0.0000 & 20.8675 & 20.8675 & 15.8008 & 36.8725 & 0.0000 & 0.0000 & 10.9535 \\
\hline M & 10.5931 & 0.0000 & 0.0000 & 0.0000 & 0.0000 & 34.8223 & 4.1334 & 3.3641 \\
\hline \multicolumn{9}{|c|}{ Foreign Resource Transfers in Domestic Currency ${ }^{2}$} \\
\hline & $20,972.4$ & $-80,102.6$ & $-16,026.5$ & $-10,884.5$ & $-26,662.9$ & $-23,081.5$ & $35,013.3$ & $352,576.6$ \\
\hline
\end{tabular}

1 Model tariff rates on exports are set equal to zero, the US imports both goods, with the trade imbalance financed by a resource transfer from abroad.

2 Footnote from Table 1. 


\section{Some Calculations of Distance Measures for a Sample of OECD Economies}

We have implemented calculations of globalization distance measures for the eight OECD countries chosen in our sample for the year 2000 (Australia, Germany, Italy, Japan, Korea, Mexico, the UK, and the US). To make these calculations we first calibrate each country model as described above and then proceed to compute a trade barrier change equilibrium as our counterfactual in each case. We then compare the initial equilibrium with the trade barrier change equilibria.

As we note above, due to the near linearity of the production frontier in the $2 \times 2$ case (see Johnson (1966), and Abrego and Whalley (2001)) specialization occurs as the equilibrium outcome with most country models in the tariff elimination case (the US, the UK, and Australia) are the exceptions. We therefore compute three different sets of globalization metrics for the country models. One is with an $8 \%$ common reduction in tariff rates in all countries since this is the maximal common reduction possible. This allows for comparability across countries since each country's tariffs are reduced by the same percentage. The second considers the largest possible reduction in the national tariff such that specialization does not occur. The advantage of this computation is that we get larger tariff reductions, in some cases complete elimination of tariffs. However, the disadvantage is that tariffs are reduced by different percentages in different countries. The third and final calculation looks at the same absolute reduction in tariff rates for each country. The maximum reduction in tariff rates sustainable without leading to specialization is $1.9 \%$. So in the third case each country faces a $1.9 \%$ reduction in all of its tariff rates. Table 4 presents the first set of results, Table 5 the second and the results for the $1.9 \%$ reduction in tariff rates are given in Table 6 . 
Table 4 Globalization Metrics for a Common $8 \%$ Reduction in Tariff Rate for a Sample of OECD Countries

\begin{tabular}{|c|c|c|c|c|c|c|c|c|}
\hline Metrics & Australia & Germany & Italy & Japan & Korea & Mexico & UK & US \\
\hline \multicolumn{9}{|c|}{ Tariff Rate Change } \\
\hline NM & 0.000000 & 0.208675 & 0.208675 & 0.158008 & 0.368725 & 0.000000 & 0.000000 & 0.109535 \\
\hline \multirow[t]{2}{*}{ M } & 0.105931 & 0.000000 & 0.000000 & 0.000000 & 0.000000 & 0.348223 & 0.041334 & 0.033641 \\
\hline & $\downarrow$ & $\downarrow$ & $\downarrow$ & $\downarrow$ & $\downarrow$ & $\downarrow$ & $\downarrow$ & $\downarrow$ \\
\hline NM & 0.000000 & 0.191981 & 0.191981 & 0.145367 & 0.339227 & 0.000000 & 0.000000 & 0.100772 \\
\hline M & 0.097456 & 0.000000 & 0.000000 & 0.000000 & 0.000000 & 0.320365 & 0.038027 & 0.030950 \\
\hline \multicolumn{9}{|c|}{ Euclidean Distance Measures } \\
\hline$M_{B}$ & 0.017811 & 0.061041 & 0.030250 & 0.033446 & 0.062720 & 0.184693 & 0.004956 & 0.013891 \\
\hline$M_{P}$ & 0.008064 & 0.015174 & 0.015174 & 0.011750 & 0.025062 & 0.023868 & 0.003242 & 0.008577 \\
\hline$M_{Q}$ & 0.035139 & 0.130947 & 0.053118 & 0.075660 & 0.107683 & 1.741749 & 0.004313 & 0.023990 \\
\hline$M_{X}$ & 0.049851 & 0.203774 & 0.085114 & 0.120297 & 0.205375 & 2.648417 & 0.006152 & 0.034914 \\
\hline$M_{T}$ & 0.005717 & 0.014704 & 0.007603 & 0.005880 & 0.021365 & 0.312117 & 0.001528 & 0.002088 \\
\hline \multicolumn{9}{|c|}{ Excess Demand Measures } \\
\hline$M F_{1}$ & 0.008876 & 0.016166 & 0.012843 & 0.012785 & 0.021072 & 0.142613 & 0.001620 & 0.005427 \\
\hline$M F_{2}$ & 0.008757 & 0.018976 & 0.013228 & 0.013567 & 0.021974 & 0.070413 & 0.001618 & 0.005514 \\
\hline$M G_{1}$ & 0.498664 & 0.551121 & 0.302689 & 0.318401 & 0.650488 & 1.312605 & 0.168093 & 0.187149 \\
\hline$M G_{2}$ & 0.472607 & 0.448203 & 0.269251 & 0.263651 & 0.581470 & 0.222766 & 0.166499 & 0.186741 \\
\hline \multicolumn{9}{|c|}{ Debreu Shrinkage Measures } \\
\hline$M D_{1}$ & -0.001384 & -0.008777 & -0.003937 & -0.003981 & -0.012864 & -0.159362 & -0.000083 & -0.000652 \\
\hline$M D_{2}$ & 0.001386 & 0.008856 & 0.003953 & 0.003997 & 0.013035 & 0.189577 & 0.000083 & 0.000652 \\
\hline
\end{tabular}


Table 5 Globalization Tariff Metrics for a Sample of OECD Countries where Maximium Possible Reductions in Tariff Rates Occur

\begin{tabular}{|c|c|c|c|c|c|c|c|c|}
\hline Metrics & Australia & Germany & Italy & Japan & Korea & Mexico & UK & US \\
\hline \multicolumn{9}{|c|}{ Tariff Rate Change } \\
\hline $\mathrm{NM}$ & 0.000000 & 0.208675 & 0.208675 & 0.158008 & 0.368725 & 0.000000 & 0.000000 & 0.109535 \\
\hline \multirow[t]{2}{*}{$\mathrm{M}$} & 0.105931 & 0.000000 & 0.000000 & 0.000000 & 0.000000 & 0.348223 & 0.041334 & 0.033641 \\
\hline & $\downarrow$ & $\downarrow$ & $\downarrow$ & $\downarrow$ & $\downarrow$ & $\downarrow$ & $\downarrow$ & $\downarrow$ \\
\hline $\mathrm{NM}$ & 0.000000 & 0.189550 & 0.082779 & 0.125721 & 0.260000 & 0.000000 & 0.000000 & 0.000000 \\
\hline M & 0.000000 & 0.000000 & 0.000000 & 0.000000 & 0.000000 & 0.318750 & 0.000000 & 0.000000 \\
\hline \multicolumn{9}{|c|}{ Euclidean Distance Measures } \\
\hline$M_{B}$ & 0.233503 & 0.068459 & 0.210283 & 0.081843 & 0.227912 & 0.194858 & 0.062120 & 0.158944 \\
\hline$M_{P}$ & 0.105931 & 0.019125 & 0.125897 & 0.032287 & 0.108725 & 0.029473 & 0.041334 & 0.114584 \\
\hline$M_{Q}$ & 0.717596 & 0.145425 & 0.309497 & 0.170203 & 0.337117 & 2.115240 & 0.058251 & 0.239993 \\
\hline$M_{X}$ & 1.036370 & 0.226255 & 0.539441 & 0.276936 & 0.686069 & 3.272022 & 0.082343 & 0.360016 \\
\hline$M_{T}$ & 0.068532 & 0.016205 & 0.061315 & 0.012864 & 0.071136 & 0.376297 & 0.018861 & 0.031064 \\
\hline \multicolumn{9}{|c|}{ Excess Demand Measures } \\
\hline$M F_{1}$ & 0.181606 & 0.017950 & 0.077043 & 0.028939 & 0.069163 & 0.176719 & 0.021860 & 0.054615 \\
\hline$M F_{2}$ & 0.138559 & 0.021491 & 0.090467 & 0.033142 & 0.077544 & 0.077322 & 0.021414 & 0.064296 \\
\hline$M G_{1}$ & 0.885209 & 0.562865 & 0.488009 & 0.389845 & 0.816065 & 1.522364 & 0.199955 & 0.193069 \\
\hline$M G_{2}$ & 0.517654 & 0.448735 & 0.302928 & 0.267422 & 0.608150 & 0.223772 & 0.177853 & 0.188212 \\
\hline \multicolumn{9}{|c|}{ Debreu Shrinkage Measures } \\
\hline$M D_{1}$ & -0.011845 & -0.009712 & -0.018332 & -0.008516 & -0.037212 & -0.189353 & -0.000565 & -0.003818 \\
\hline$M D_{2}$ & 0.011985 & 0.009808 & 0.018679 & 0.008589 & 0.038688 & 0.233587 & 0.000566 & 0.003832 \\
\hline
\end{tabular}


Table 6 Globalization Metrics for a Common Reduction 0.01912494 in Tariff Rate for a Sample of OECD Countries

\begin{tabular}{|c|c|c|c|c|c|c|c|c|}
\hline Metrics & Australia & Germany & Italy & Japan & Korea & Mexico & UK & US \\
\hline \multicolumn{9}{|c|}{ Tariff Rate Change } \\
\hline $\mathrm{NM}$ & 0.000000 & 0.208675 & 0.208675 & 0.158008 & 0.368725 & 0.000000 & 0.000000 & 0.109535 \\
\hline \multirow[t]{2}{*}{$\mathrm{M}$} & 0.105931 & 0.000000 & 0.000000 & 0.000000 & 0.000000 & 0.348223 & 0.041334 & 0.033641 \\
\hline & $\downarrow$ & $\downarrow$ & $\downarrow$ & $\downarrow$ & $\downarrow$ & $\downarrow$ & $\downarrow$ & $\downarrow$ \\
\hline $\mathrm{NM}$ & 0.000000 & 0.189550 & 0.189550 & 0.138883 & 0.349600 & 0.000000 & 0.000000 & 0.090410 \\
\hline M & 0.086806 & 0.000000 & 0.000000 & 0.000000 & 0.000000 & 0.329098 & 0.022209 & 0.014516 \\
\hline \multicolumn{9}{|c|}{ Euclidean Distance Measures } \\
\hline$M_{B}$ & 0.040503 & 0.069158 & 0.034584 & 0.049879 & 0.040911 & 0.113429 & 0.028831 & 0.025720 \\
\hline$M_{P}$ & 0.018246 & 0.017393 & 0.017393 & 0.017804 & 0.016213 & 0.016355 & 0.018826 & 0.025467 \\
\hline$M_{Q}$ & 0.082556 & 0.145425 & 0.060408 & 0.109474 & 0.071759 & 0.755415 & 0.025735 & 0.006022 \\
\hline$M_{X}$ & 0.117143 & 0.226255 & 0.096970 & 0.175386 & 0.135584 & 1.105619 & 0.036558 & 0.008746 \\
\hline$M_{T}$ & 0.012892 & 0.016205 & 0.008705 & 0.008400 & 0.014164 & 0.139410 & 0.008795 & 0.000499 \\
\hline \multicolumn{9}{|c|}{ Excess Demand Measures } \\
\hline$M F_{1}$ & 0.020840 & 0.017950 & 0.014616 & 0.018538 & 0.013951 & 0.059060 & 0.009662 & 0.001361 \\
\hline$M F_{2}$ & 0.020190 & 0.021491 & 0.015114 & 0.020212 & 0.014353 & 0.042055 & 0.009578 & 0.001356 \\
\hline$M G_{1}$ & 0.517532 & 0.562865 & 0.308016 & 0.344006 & 0.624029 & 0.715664 & 0.180748 & 0.186633 \\
\hline$M G_{2}$ & 0.477211 & 0.448735 & 0.270035 & 0.264954 & 0.577770 & 0.218647 & 0.171137 & 0.186734 \\
\hline \multicolumn{9}{|c|}{ Debreu Shrinkage Measures } \\
\hline$M D_{1}$ & -0.003067 & -0.009712 & -0.004458 & -0.005665 & -0.008658 & -0.073931 & -0.000395 & 0.000171 \\
\hline$M D_{2}$ & 0.003076 & 0.009808 & 0.004478 & 0.005698 & 0.008735 & 0.079834 & 0.000395 & -0.000171 \\
\hline
\end{tabular}


The degree of globalization or integration is decreasing in the distance of the measures from zero. That is, countries in which the globalization measures are closest to zero are the most globalized. Considering Tables 4,5 and 6 we find that these results are interesting and in some ways surprising. Looking at all three tariff reduction exercises it is clear that there is no consistency across the measures for any of the sampled countries. Consider the case of Australia as given in Column 1 of Table 4 . An $8 \%$ reduction in the tariff rate reveals a $50 \%$ distance measure under measure $M G_{1}$, but only a less then $1 \%$ measure for the Debreu shrinkage measures, $M D_{1}$, and $M D_{2}$. Within the Euclidean distance measure group measures differ by a factor of nearly 10. Similar features occur in every country case (i.e. in results down each column of Table 4). The results for Tables 5 and 6 are similar. Looking at these numbers, then, one cannot draw any conclusion as to whether an $8 \%$ tariff reduction moves countries considerably closer to or only little closer to global integration.

In addition, it is not clear how to choose between these different measures. For some measures there are very large differences across countries while for other measures cross country differences are small. For example, looking at Table 4 (a common $8 \%$ tariff reduction) the distance measure $M_{X}$ varies from a low of 0.0061 for the UK to a high of 2.6484 for Mexico. On the other hand, the distance measure $M_{P}$ only varies from 0.0032 (UK) to 0.0238 (Mexico).

On the whole, given that the common $8 \%$ reduction in tariff rates yields a larger absolute tariff change in countries with higher initial tariffs, such as Mexico, results for such countries show higher measures than for low initial tariff rate countries, such as the UK. To adjust for this in Table 6 we look at the same absolute tariff reduction for all countries. The rate reduction we look at is about $2 \%$ and what we find is that, as expected, the numbers get closer together. For example, for $M_{X}$ the range shrinks from a low of 0.0087 (US) to a high of 1.1056 (Mexico.) All of the $M_{P}$ numbers are close. The range is 0.01629 (Korea) to 0.0254 (US.) However, the property that there are large differences across measures still holds in Table 6. Based on the results to this point we thus conclude that both constructing and interpreting measures of globalization distance is at best a difficult matter given all these differences in the behavior of measures.

\subsection{Ordinal Measures}

The results to this point appear quite negative. The different globalization measures we have chosen do not seem to yield a coherent way to measure the degree of globalization for any 
particular country. Looking down the columns of Tables 4, 5, and 6 we see that there are large differences in globalization measures for each country for a given tariff change. In addition, looking at the rows of the tables we see that the variability of measures differs widely. In fact, if we compute the variances of each of the rows of Table 4, for example, those variances range between 0.0000583 and 0.816742 . This leads one to ask are there any coherent patterns to these various measures?

We can give a qualified "yes" to this question if we adopt a more limited objective. It turns out that the data from these tables do shed some light on the relative degree of globalization. If instead of trying to develop an absolute measure of globalization we develop an ordinal globalization ranking we can make some progress. What we do is to take each of the eleven measures of globalization, then rank order the countries by how globalized they are. For the measures we have smaller numbers indicate more globalized countries. We do this only for Tables 4 and 6 because Table 5 has different tariff reduction for each country. In Table 7 (8) we have duplicated Table 4 (6) except in place of the actual values of each measure we have replaced them with the rankings. A ranking of 1 means that the country is the most globalized of all eight countries we consider and a ranking of 8 means that the country is the least globalized. 
Table 7 Globalization Rankings for a Common $8 \%$ Reduction in Tariff Rate for a Sample of OECD Countries

\begin{tabular}{|c|c|c|c|c|c|c|c|c|}
\hline Metrics & Australia & Germany & Italy & Japan & Korea & Mexico & UK & US \\
\hline \multicolumn{9}{|c|}{ Tariff Rate Change } \\
\hline NM & 0.000000 & 0.208675 & 0.208675 & 0.158008 & 0.368725 & 0.000000 & 0.000000 & 0.109535 \\
\hline \multirow[t]{2}{*}{$\mathrm{M}$} & 0.105931 & 0.000000 & 0.000000 & 0.000000 & 0.000000 & 0.348223 & 0.041334 & 0.033641 \\
\hline & $\downarrow$ & $\downarrow$ & $\downarrow$ & $\downarrow$ & $\downarrow$ & $\downarrow$ & $\downarrow$ & $\downarrow$ \\
\hline NM & 0.000000 & 0.191981 & 0.191981 & 0.145367 & 0.339227 & 0.000000 & 0.000000 & 0.100772 \\
\hline $\mathrm{M}$ & 0.097456 & 0.000000 & 0.000000 & 0.000000 & 0.000000 & 0.320365 & 0.038027 & 0.030950 \\
\hline \multicolumn{9}{|c|}{ Euclidean Distance Measures } \\
\hline$M_{B}$ & 3 & 6 & 4 & 5 & 7 & 8 & 1 & 2 \\
\hline$M_{P}$ & 2 & 5 & 5 & 4 & 8 & 7 & 1 & 3 \\
\hline$M_{Q}$ & 3 & 7 & 4 & 5 & 6 & 8 & 1 & 2 \\
\hline$M_{X}$ & 3 & 6 & 4 & 5 & 7 & 8 & 1 & 2 \\
\hline$M_{T}$ & 3 & 6 & 5 & 4 & 7 & 8 & 1 & 2 \\
\hline \multicolumn{9}{|c|}{ Excess Demand Measures } \\
\hline$M F_{1}$ & 3 & 6 & 5 & 4 & 7 & 8 & 1 & 2 \\
\hline$M F_{2}$ & 3 & 6 & 4 & 5 & 7 & 8 & 1 & 2 \\
\hline$M G_{1}$ & 5 & 6 & 3 & 4 & 7 & 8 & 1 & 2 \\
\hline$M G_{2}$ & 7 & 6 & 5 & 4 & 8 & 3 & 1 & 2 \\
\hline \multicolumn{9}{|c|}{ Debreu Shrinkage Measures } \\
\hline$M D_{1}$ & 3 & 6 & 4 & 5 & 7 & 8 & 1 & 2 \\
\hline$M D_{2}$ & 3 & 6 & 4 & 5 & 7 & 8 & 1 & 2 \\
\hline
\end{tabular}


Table 8 Globalization Rankings for a Common Reduction 0.01912494 in Tariff Rates for a Sample of OECD Countries ${ }^{1}$

\begin{tabular}{|c|c|c|c|c|c|c|c|c|}
\hline Metrics & Australia & Germany & Italy & Japan & Korea & Mexico & UK & US \\
\hline \multicolumn{9}{|c|}{ Tariff Rate Change } \\
\hline $\mathrm{NM}$ & 0.000000 & 0.208675 & 0.208675 & 0.158008 & 0.368725 & 0.000000 & 0.000000 & 0.109535 \\
\hline \multirow[t]{2}{*}{ M } & 0.105931 & 0.000000 & 0.000000 & 0.000000 & 0.000000 & 0.348223 & 0.041334 & 0.033641 \\
\hline & $\downarrow$ & $\downarrow$ & $\downarrow$ & $\downarrow$ & $\downarrow$ & $\downarrow$ & $\downarrow$ & $\downarrow$ \\
\hline $\mathrm{NM}$ & 0.000000 & 0.189550 & 0.189550 & 0.138883 & 0.349600 & 0.000000 & 0.000000 & 0.090410 \\
\hline M & 0.086806 & 0.000000 & 0.000000 & 0.000000 & 0.000000 & 0.329098 & 0.022209 & 0.014516 \\
\hline \multicolumn{9}{|c|}{ Euclidean Distance Measures } \\
\hline$M_{B}$ & 4 & 7 & 3 & 6 & 5 & 8 & 2 & 1 \\
\hline$M_{P}$ & 6 & 3 & 4 & 5 & 1 & 2 & 7 & 8 \\
\hline$M_{Q}$ & 5 & 7 & 3 & 6 & 4 & 8 & 2 & 1 \\
\hline$M_{X}$ & 4 & 7 & 3 & 6 & 5 & 8 & 2 & 1 \\
\hline$M_{T}$ & 5 & 7 & 3 & 2 & 6 & 8 & 4 & 1 \\
\hline \multicolumn{9}{|c|}{ Excess Demand Measures } \\
\hline$M F_{1}$ & 7 & 5 & 4 & 6 & 3 & 8 & 2 & 1 \\
\hline$M F_{2}$ & 5 & 7 & 4 & 6 & 3 & 8 & 2 & 1 \\
\hline$M G_{1}$ & 5 & 6 & 3 & 4 & 7 & 8 & 1 & 2 \\
\hline$M G_{2}$ & 7 & 6 & 5 & 4 & 8 & 3 & 1 & 2 \\
\hline \multicolumn{9}{|c|}{ Debreu Shrinkage Measures } \\
\hline$M D_{1}$ & 3 & 7 & 4 & 5 & 6 & 8 & 2 & 1 \\
\hline$M D_{2}$ & 3 & 7 & 4 & 5 & 6 & 8 & 2 & 1 \\
\hline
\end{tabular}


Looking at Table 6 there are clear patterns of relative rankings. The UK is the most globalized country for every ranking and the US is the second most globalized for all but one measure. Mexico is the least globalized country and Korea is the next least globalized. Table 9 demonstrates a similar pattern, although the pattern of rankings does not appear to be as clear cut as in Table 6. The US and UK appear to be the most globalized countries, while Mexico and Germany seem to be the least globalized.

To try and quantify these rankings further we do a simple aggregation of the rankings for all measures. What we do is simply add up the rankings and report the scores for both Tables 7 and 8 in Table 9 . For the aggregate rankings a lower aggregate ranking means a more globalized country. This table shows that the measures used here produce a fairly clear measure of the relative level of globalization across countries. This suggests that while obtaining quantitatively meaningful measures of globalization may be extremely difficult, obtaining relative globalization rankings may be an obtainable goal.

Table 9 Aggregate Globalization Rankings

\begin{tabular}{|c|c|c|}
\hline Country & Aggregate Score-Table 7 & Aggregate Score-Table 8 \\
\hline Australia & 38 & 54 \\
Germany & 66 & 69 \\
Italy & 47 & 40 \\
Japan & 50 & 55 \\
Korea & 78 & 54 \\
Mexico & 82 & 77 \\
UK & 11 & 27 \\
US & 23 & 20 \\
\hline
\end{tabular}




\section{Sensitivity Analysis}

We have performed further calculations with the country calibrated models which allow us to investigate the sensitivity of distance measures with respect to critical model parameters, such as elasticities of substitution, and with respect to the depth of tariff cuts in particular cases. For simplicity these sensitivity analyses are presented for only one country, the US. These are displayed graphically in Figures 1 and 2.

What is striking about the results in Figure 1 is the near independence of some measures to elasticities and extreme sensitivity in other cases. Euclidean distance measures (which themselves are sharply different one from another) vary little, but excess demand measures vary more (especially for $M F_{2}$ ). Debreu shrinkage measures vary proportionally but little in absolute value across elasticity values.

Figure 2 reports the variation of distance measures with the size of the tariff reduction, since the US is a country case where tariff elimination is possible without specialization occurring. Here, Euclidean distance measures behave similarly in proportional terms across different depth of tariff cuts, being roughly linear in the depth of cut. Excess factor demand measures are also nearly linear and behave equiproportionally. Debreu shrinkage measures behave in a non-linear way. 


\section{Figure 1 Sensitivity of US Globalization Measures to Substitution Elasticity Parameter Value (in Sector Non Manufacturing)}

1.1 Euclidean Distance Measures

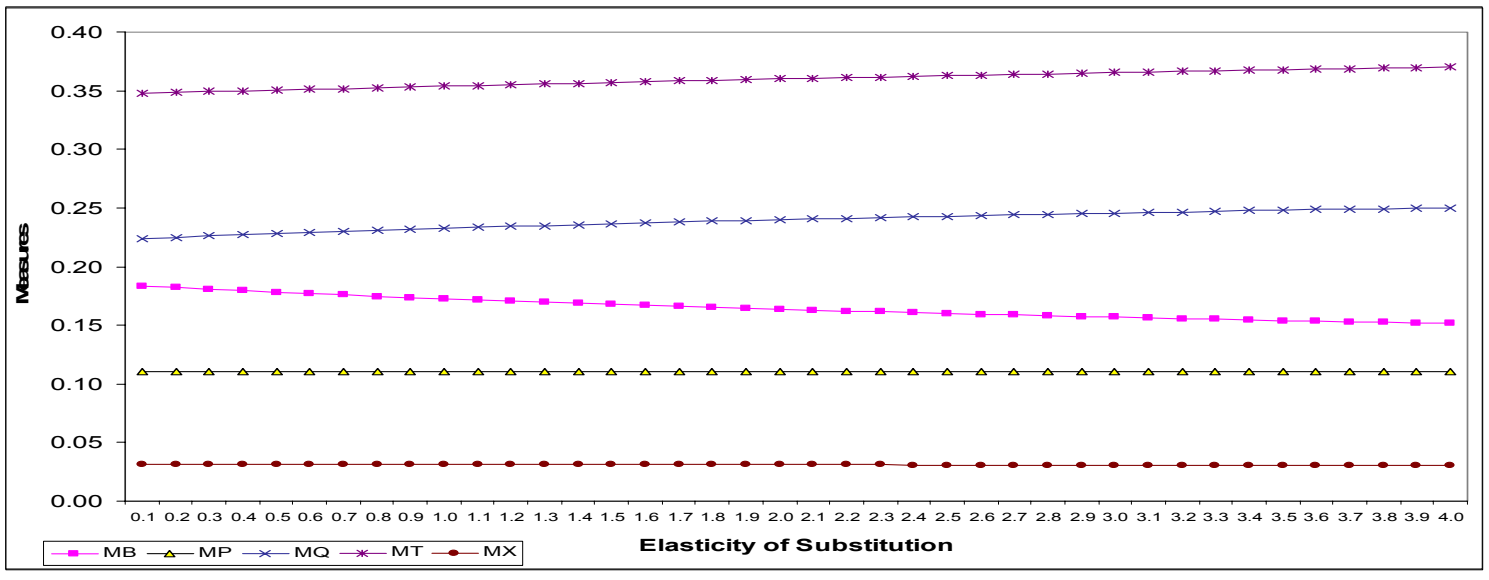

1.2 Excess Demand Measures

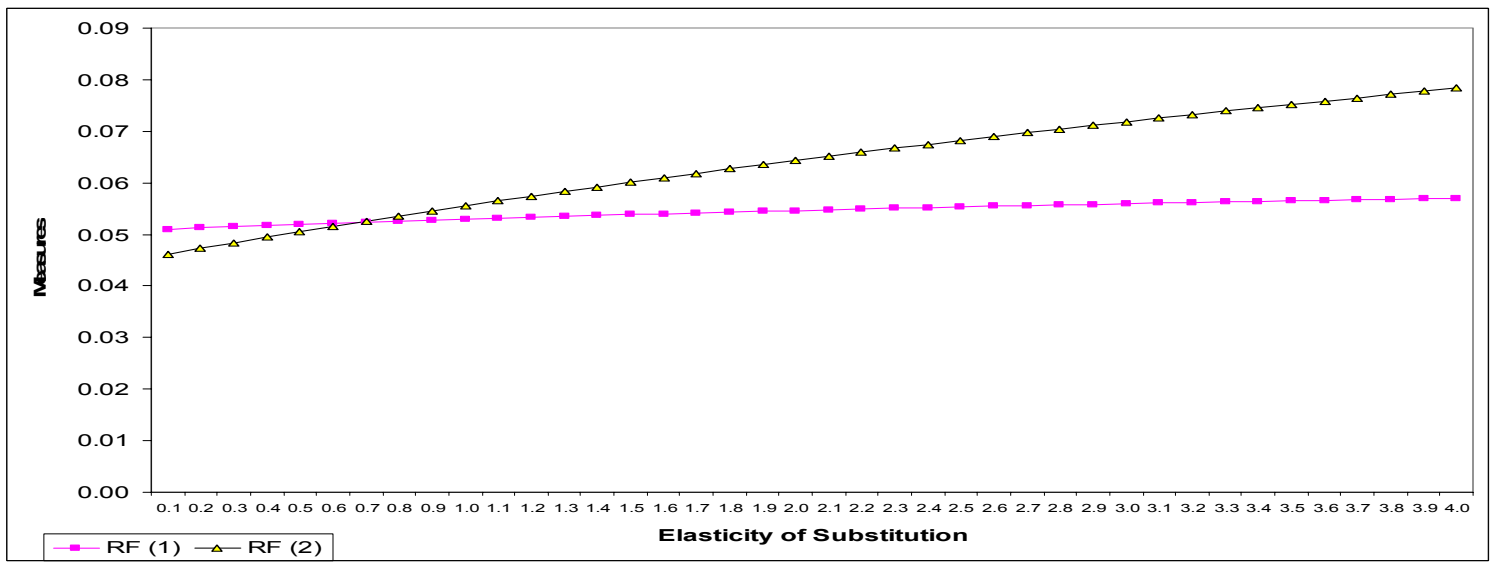

1.3 Debreu Shrinkage Measures

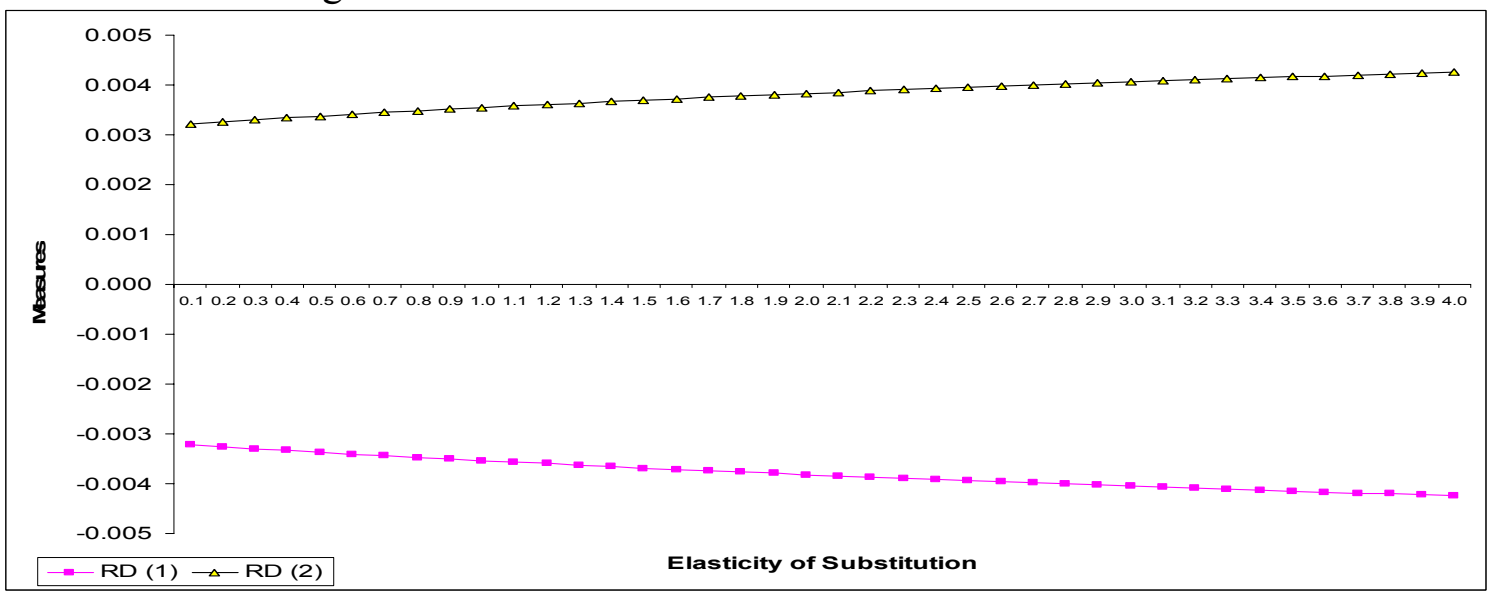




\section{Figure 2 Sensitivity of US Globalization Measures to the Depth of}

\section{Tariff Reduction}

2.1 Euclidean Distance Measures

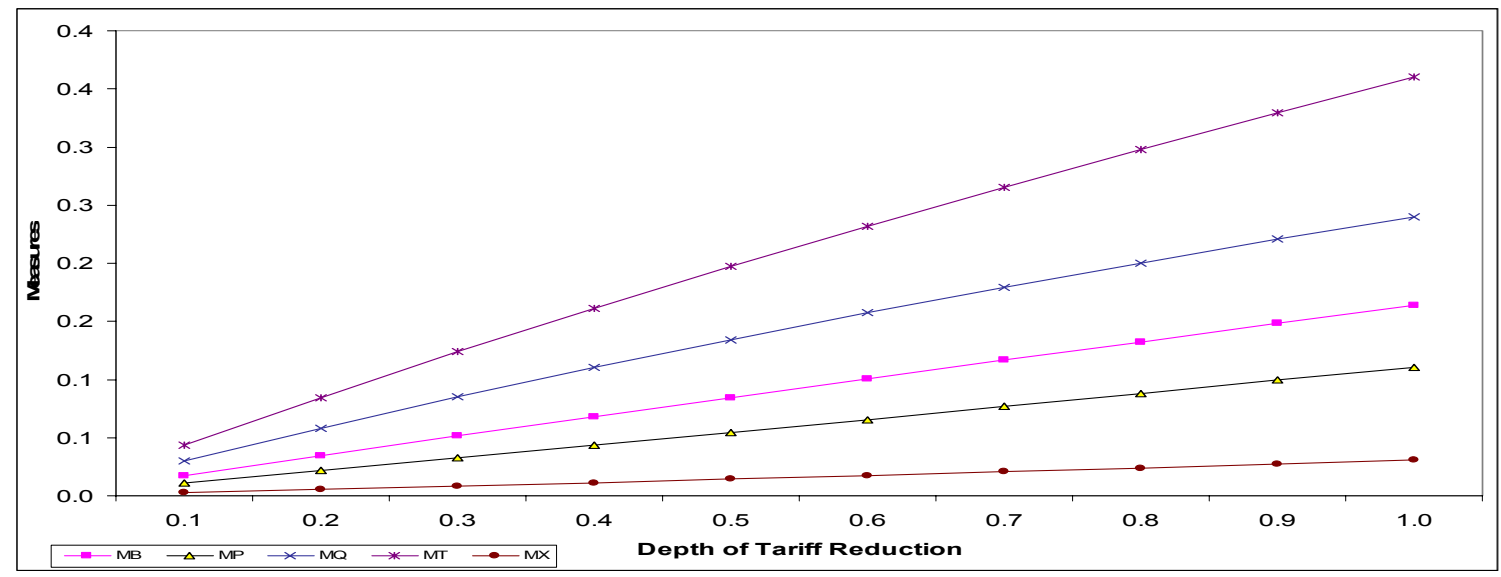

2.2 Excess Demand Measures

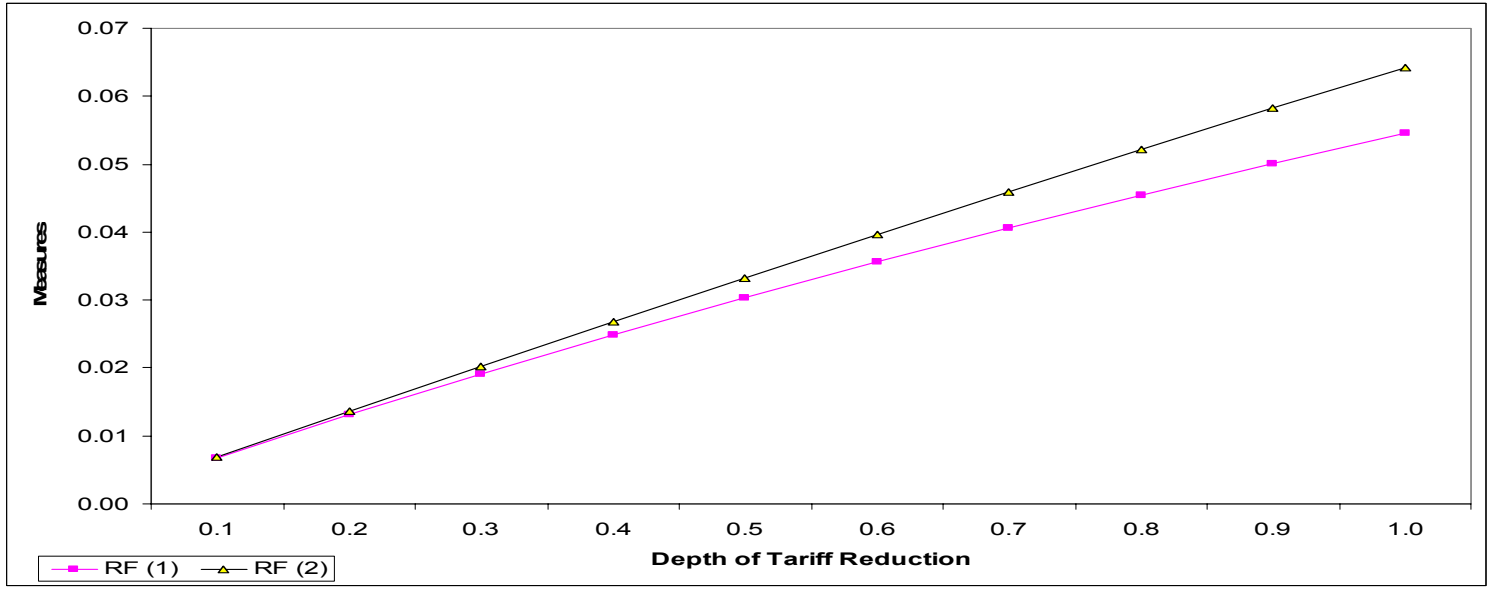

2.3 Debreu Shrinkage Measures

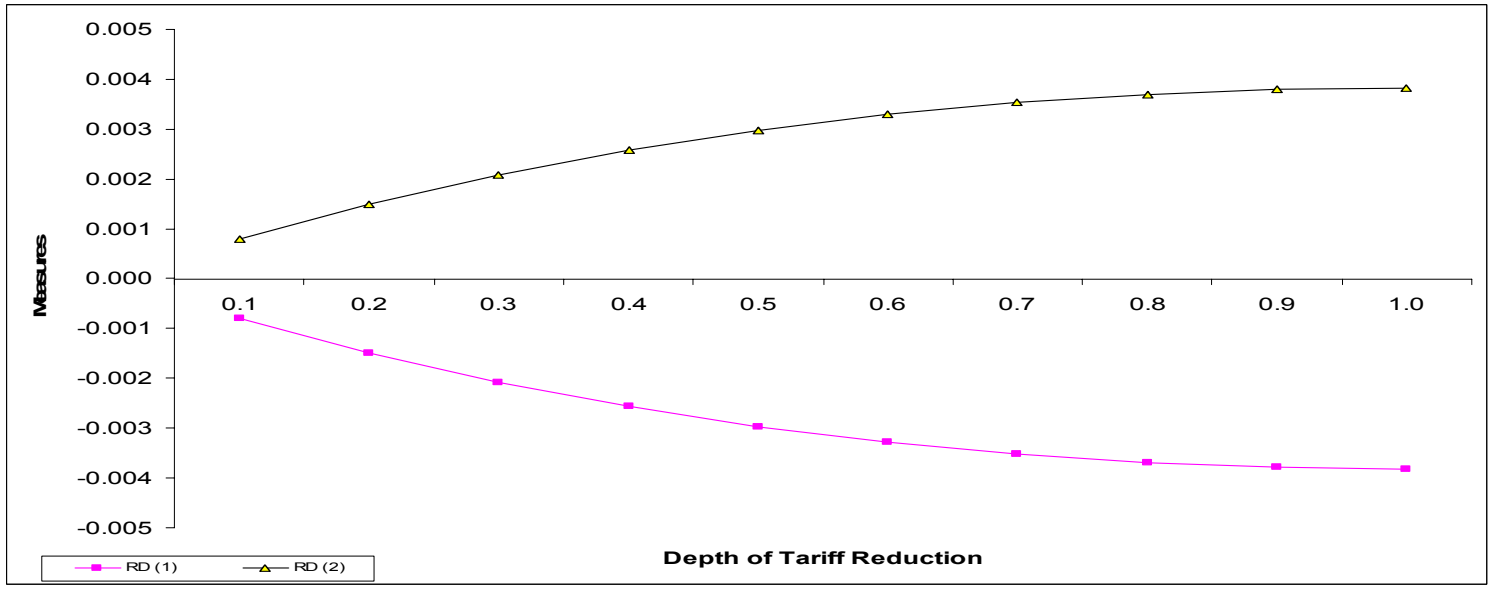




\section{Conclusion}

Our conclusion from these calculations is that just as the many measures of inequality in the income inequality literature yield different and non-comparable partial orderings, so with globalization measures (and equilibrium metrics in general) there are many available measures whose numerical behavior will differ. Which to use, and how to interpret such metrics when calculated is not clear. Seemingly measures will also vary with the degree of disaggregation in models, the structural form of models, and the treatment of factor flows and barriers. Making sense out of the numbers which currently circulate thus seems to be a hazardous occupation.

In this paper we have discussed possible metrics of globalization for countries constructed as distance measures between barrier restricted and more globally integrated country equilibria. In the process we also emphasize that literature on equilibrium metrics in general is limited, and so our paper is part of a wider discussion of possible metrics of distance across equilibria.

Our results which we report for a sample of eight OECD countries using 2000 data applied to simple $2 \times 2$ country models suggest both substantial differences in measures for a single country and differences across country in measures for the same barrier reduction. As such, our results are on the whole negative, but they do illustrate the many pitfalls involved with measures currently reported in popular magazines such as the Economist and Foreign Policy. When we lower our sights a bit and ask whether these different measures contain any information about the degree of globalization there does seem to be information in them about the relative degree of globalization of different countries. The measures we look at do suggest which countries are more globalized relative to other countries. Developing relative rankings appears to hold promise for future research.

Our findings may appear to those outside the area to be too negative, and our tone overly pessimistic on the measurement front so far as quantifying globalization is concerned. But little literature exists on these issues and our hope is that our paper might spark further work in the area that will advance on what we have to offer. Our belief is that we are indeed moving to an increasingly integrated global economy in terms of goods flows and capital markets, but with more segmentation in labour markets, where the global costs of restrictions are large ${ }^{6}$. Adding in the concerns of political scientists over global governance and sociologists over global identity, to say nothing of the anti globalization protestors, may well leave globalization as an inherently unquantifiable metric; but hope springs eternal, and with fortitude and perseverance

\footnotetext{
${ }^{6}$ See Hamilton and Whalley (1984)
} 
the challenge is for a new cottage industry of globalization quantifiers to emerge to fill the gap. 


\section{References}

[1] Arrow, K.J. and F. Hahn. (1971) General Competitive Equilibrium. Mathematical Economics Texts 6, San Francisco: Holden-Day, Inc.

[2] Cable, V. (1995) The Diminished Nation-State: A Study in the Loss of Economic Power. Daedalus (Spring 1995).

[3] Cable, V. and A. Bressand. (2000) Globalization: Rules and Standards for the World Economy. Chatham House Papers, Thomson Learning.

[4] Debreu, G. (1951) The Coefficient of Resource Utilization. Econometrica 19 (3), 273 292.

[5] Dawkins, C., T.N. Srinivasan, and J. Whalley. (2001) Calibration. in J.Heckman and E. Leamer (Eds) Handbook of Econometrics, Volume 5, 3653 - 3703. New York, N.Y.: Elsevier Science Publishing. Co.

[6] Foreign Policy, Measuring Global. March - April 2004, Page 54 - 69.

[7] Hamilton, R.W. and J. Whalley. (1984) Efficiency and Distributional Implications of Global Restrictions on Labour Mobility: Calculations and Policy Implications. Journal of Development Economics 14 (1-2), 61-75.

[8] Hammermesh, D. (1993) Labour Demand Elasticities. The World Economy 24 (1), 15 30.

[9] Harberger, A.C. (1962) The Incidence of the Corporate Tax. Journal of Political Economy $70(3), 215-240$.

[10] Irwin, D.A. (2001) Tariffs and Growth in Late Nineteenth Century America. The World Economy 24 (1), 15 - 30.

[11] Kehoe, T. (1991) Computation and Multiplicity of Equilibria. in W. Hildenbrand and H. Sonnenschein (Eds) Handbook of Mathematical Economics, volume 4, 2049-2143. North Holland.

[12] Mas-Colell, A. (1985) The Theory of General Economic Equilibrium - A Differentiable Approach. Econometric Society Monographs 9, Cambridge University Press. 
[13] Piggott, J.R. and J. Whalley. (1985) UK Tax Policy and Applied General Equilibrium Analysis. Cambridge: Cambridge University Press.

[14] Shoven, J.B. and J. Whalley. (1992) Applying General Equilibrium. Cambridge University Press.

[15] Whalley, J. (2004) Globalization and Values. Paper Prepared for CES-ifo Conference "Dissecting Globalization", Vince, July 21 - 23, 2004.

[16] Whalley, J. and S. Zhang. (2004) Surfing the Manifolds of An Economy with Five Equilibria. Research Paper, Department of Economics, The University of Western Ontario. 


\title{
CESifo Working Paper Series
}

\author{
(for full list see www.cesifo.de)
}

1386 Alfred Greiner, Uwe Koeller and Willi Semmler, Testing Sustainability of German Fiscal Policy. Evidence for the Period 1960 - 2003, January 2005

1387 Gebhard Kirchgässner and Tobias Schulz, Expected Closeness or Mobilisation: Why Do Voters Go to the Polls? Empirical Results for Switzerland, 1981 - 1999, January 2005

1388 Emanuele Bacchiocchi and Alessandro Missale, Managing Debt Stability, January 2005

1389 Assar Lindbeck and Dirk Niepelt, Improving the SGP: Taxes and Delegation rather than Fines, January 2005

1390 James J. Heckman and Dimitriy V. Masterov, Skill Policies for Scotland, January 2005

1391 Emma Galli \& Fabio Padovano, Sustainability and Determinants of Italian Public Deficits before and after Maastricht, January 2005

1392 Angel de la Fuente and Juan Francisco Jimeno, The Private and Fiscal Returns to Schooling and the Effect of Public Policies on Private Incentives to Invest in Education: A General Framework and Some Results for the EU, January 2005

1393 Juan C. Conesa and Carlos Garriga, Optimal Response to a Demographic Shock, January 2005

1394 Christian Gollier, Optimal Portfolio Management for Individual Pension Plans, February 2005

1395 Ruslan Lukach, Joseph Plasmans and Peter M. Kort, Innovation Strategies in a Competitive Dynamic Setting, February 2005

1396 Gebhard Kirchgässner, (Why) Are Economists Different?, February 2005

1397 Marko Köthenbürger, Panu Poutvaara and Paola Profeta, Why are More Redistributive Social Security Systems Smaller? A Median Voter Approach, February 2005

1398 Gabrielle Demange, Free Choice of Unfunded Systems: A First Assessment, February 2005

1399 Carlos Fonseca Marinheiro, Sustainability of Portuguese Fiscal Policy in Historical Perspective, February 2005

1400 Roel M. W. J. Beetsma and Koen Vermeylen, The Effect of Monetary Unification on Public Debt and its Real Return, February 2005

1401 Frank Asche, Petter Osmundsen and Maria Sandsmark, Is It All Oil?, February 2005 
1402 Giacomo Corneo, Media Capture in a Democracy: The Role of Wealth Concentration, February 2005

1403 A. Lans Bovenberg and Thijs Knaap, Ageing, Funded Pensions and the Dutch Economy, February 2005

1404 Thiess Büttner, The Incentive Effect of Fiscal Equalization Transfers on Tax Policy, February 2005

1405 Luisa Fuster, Ayşe İmrohoroğlu and Selahattin İmrohoroğlu, Personal Security Accounts and Mandatory Annuitization in a Dynastic Framework, February 2005

1406 Peter Claeys, Policy Mix and Debt Sustainability: Evidence from Fiscal Policy Rules, February 2005

1407 James M. Malcomson, Supplier Discretion over Provision: Theory and an Application to Medical Care, February 2005

1408 Thorvaldur Gylfason, Interview with Assar Lindbeck, February 2005

1409 Christian Gollier, Some Aspects of the Economics of Catastrophe Risk Insurance, February 2005

1410 Gebhard Kirchgässner, The Weak Rationality Principle in Economics, February 2005

1411 Carlos José Fonseca Marinheiro, Has the Stability and Growth Pact Stabilised? Evidence from a Panel of 12 European Countries and Some Implications for the Reform of the Pact, February 2005

1412 Petter Osmundsen, Frank Asche, Bård Misund and Klaus Mohn, Valuation of International Oil Companies -The RoACE Era, February 2005

1413 Gil S. Epstein and Shmuel Nitzan, Lobbying and Compromise, February 2005

1414 Marcel F. M. Canoy, Jan C. van Ours and Frederick van der Ploeg, The Economics of Books, February 2005

1415 Eric A. Hanushek and Ludger Wößmann, Does Educational Tracking Affect Performance and Inequality? Differences-in-Differences Evidence across Countries, February 2005

1416 George Kapetanios and M. Hashem Pesaran, Alternative Approaches to Estimation and Inference in Large Multifactor Panels: Small Sample Results with an Application to Modelling of Asset Returns, February 2005

1417 Samuel Mühlemann, Jürg Schweri, Rainer Winkelmann and Stefan C. Wolter, A Structural Model of Demand for Apprentices. February 2005

1418 Giorgio Brunello and Lorenzo Rocco, Educational Standards in Private and Public Schools, February 2005 
1419 Alex Bryson, Lorenzo Cappellari and Claudio Lucifora, Why so Unhappy? The Effects of Unionisation on Job Satisfaction, March 2005

1420 Annalisa Luporini, Relative Performance Evaluation in a Multi-Plant Firm, March 2005

1421 Giorgio Bellettini and Carlotta Berti Ceroni, When the Union Hurts the Workers: A Positive Analysis of Immigration Policy, March 2005

1422 Pieter Gautier, Michael Svarer and Coen Teulings, Marriage and the City, March 2005

1423 Ingrid Ott and Stephen J. Turnovsky, Excludable and Non-Excludable Public Inputs: Consequences for Economic Growth, March 2005

1424 Frederick van der Ploeg, Back to Keynes?, March 2005

1425 Stephane Dees, Filippo di Mauro, M. Hashem Pesaran and L. Vanessa Smith, Exploring the International Linkages of the Euro Area: a Global VAR Analysis, March 2005

1426 Hans Pitlik, Friedrich Schneider and Harald Strotmann, Legislative Malapportionment and the Politicization of Germany's Intergovernmental Transfer System, March 2005

1427 Konstantinos Angelopoulos and Apostolis Philippopoulos, The Role of Government in Anti-Social Redistributive Activities, March 2005

1428 Ansgar Belke and Daniel Gros, Asymmetries in the Trans-Atlantic Monetary Policy Relationship: Does the ECB follow the Fed?, March 2005

1429 Sören Blomquist and Luca Micheletto, Optimal Redistributive Taxation when Government's and Agents' Preferences Differ, March 2005

1430 Olof Åslund and Peter Fredriksson, Ethnic Enclaves and Welfare Cultures - QuasiExperimental Evidence, March 2005

1431 Paul De Grauwe, Roberto Dieci and Marianna Grimaldi, Fundamental and NonFundamental Equilibria in the Foreign Exchange Market. A Behavioural Finance Framework, March 2005

1432 Peter Egger, Stefan Gruber, Mario Larch and Michael Pfaffermayr, Knowledge-Capital Meets New Economic Geography, March 2005

1433 George Economides and Apostolis Philippopoulos, Should Green Governments Give Priority to Environmental Policies over Growth-Enhancing Policies?, March 2005

1434 George W. Evans and Seppo Honkapohja, An Interview with Thomas J. Sargent, March 2005

1435 Helge Berger and Volker Nitsch, Zooming Out: The Trade Effect of the Euro in Historical Perspective, March 2005 
1436 Marc-Andreas Muendler, Rational Information Choice in Financial Market Equilibrium, March 2005

1437 Martin Kolmar and Volker Meier, Intra-Generational Externalities and InterGenerational Transfers, March 2005

1438 M. Hashem Pesaran and Takashi Yamagata, Testing Slope Homogeneity in Large Panels, March 2005

1439 Gjermund Nese and Odd Rune Straume, Industry Concentration and Strategic Trade Policy in Successive Oligopoly, April 2005

1440 Tomer Blumkin and Efraim Sadka, A Case for Taxing Education, April 2005

1441 John Whalley, Globalization and Values, April 2005

1442 Denise L. Mauzerall, Babar Sultan, Namsoug Kim and David F. Bradford, Charging $\mathrm{NO}_{x}$ Emitters for Health Damages: An Exploratory Analysis, April 2005

1443 Britta Hamburg, Mathias Hoffmann and Joachim Keller, Consumption, Wealth and Business Cycles in Germany, April 2005

1444 Kohei Daido and Hideshi Itoh, The Pygmalion Effect: An Agency Model with Reference Dependent Preferences, April 2005

1445 John Whalley, Rationality, Irrationality and Economic Cognition, April 2005

1446 Henning Bohn, The Sustainability of Fiscal Policy in the United States, April 2005

1447 Torben M. Andersen, Is there a Role for an Active Fiscal Stabilization Policy? April 2005

1448 Hans Gersbach and Hans Haller, Bargaining Power and Equilibrium Consumption, April 2005

1449 Jerome L. Stein, The Transition Economies: A NATREX Evaluation of Research, April 2005

1450 Raymond Riezman, John Whalley and Shunming Zhang, Metrics Capturing the Degree to which Individual Economies are Globalized, April 2005 